\title{
THE LUNAR SOCIETY OF BIRMINGHAM
}

\author{
By D. G. KING-HELE \\ Royal Aircraft Establishment, Farnborough
}

Is the English midlands two hundred years ago, when the Moon was full, something unique in the history of science and technology was beginning - the Lunar Society of Birmingham. It had no organization, and no records of its meetings were kept, so that a hardened sceptic might call it a non-society: it was just "a group of philosophers who met at about the time of the full Moon", and they were familiarly known as "the Lunaticks". The very informality of the Society was its strength, for the interests, enterprise and intelligence of the members reacted on each other in an extraordinarily fruitful way. Their combined individual achievements came to provide one of the chief driving forces behind the industrial revolution in Britain, which in turn was the main spur to the developments in the nineteenth century that have led to the modern technological world.

The birth-date of the Society is disputable, because it just grew, out of the friendship between Matthew Boulton and Erasmus Darwin. 1766 is probably the best date to choose, however, and that is why a fine bicentenary exhibition is now being held at the Birmingham Museum and Art Gallery (open from October 13 to November 27), and a commemorative silver medallion is being struck by the Mint, Birmingham.

Although the Lunar Society's birth-date may be undefinable, its chronology nicely parallels the phases of the Moon, if we translate lunar weeks into Lunar decades. The $1760 \mathrm{~s}$ correspond to the Moon's first week, for the Society grew from an imperceptible crescent to a substantial semicircle. In the $1770 \mathrm{~s}$ it shone more and more brightly, reaching its fullest glory about 1780 . In the early 1780 s it retained its lustre, but by 1790 it was definitely declining. The $1790 \mathrm{~s}$ saw its final waning, as its leading spirits lost the enthusiasm which had once spurred them, without leaving any formal organization for perpetuating the meetings. By 1800, at the end of the fourth decade, the Society was virtually defunct.

The Lunar Society was very much a group of individualists, of wide interests, great talents and, perhaps most important of all, tremendous enthusiasm not only for science and technology, but also for art, education, the freeing of slaves, or anything that might make the world a better place to live in. The Society's great strength lay in the personal friendships of the members: Boulton, Darwin, Small, Wedgwood, Edgeworth, Keir, Watt, Priestley-each was a valued friend of all the others. As Edgeworth remarked, it was

"such a society, as few men have had the good fortune to live with; such an assemblage of friends, as fewer still have had the happiness to possess, and keep through life. . . . This mutual intimacy has never been broken but by death."

It was all so friendly and informal that no one would have been solemn enough to sit down and write minutes of the meetings. Consequently we do not know what a Lunar meeting was really like. In the absence of written records, the story of the Society can only be told by looking at each of its individual members and their interactions on each other.

Matthew Boulton ${ }^{2}(1728-1809)$ (Fig. 1) was the son of a Birmingham buckle-maker. The buckle factory he inherited on his father's death in 1759 was not enough to occupy a man of his intense energy and enterprise, and in 1761 he began building a fine new factory at Soho on the outskirts of Birmingham. Each year Boulton added to his commitments and his fame until he became recognized as the chief manufacturer of England and "the father of Birmingham". Yet it was not until the Boulton and Watt steam engine came into full production, about twenty years later, that the factory showed a profit. Boulton was also famous for his fine work as a silversmith, and for developing in the 1790 s the first modern coining machines, which dismayed the counterfeiters and made money for half the world.

\section{Sorry, for copyright reasons some images on this page may not be available online}

Fig. 1. Matthew Boulton. (By courtesy of the National Portrait Gallery.)

As R. E. Schofield has emphasized in his authoritative history of the Lunar Society ${ }^{3}$, Boulton was the leading spirit in the Society: we might almost-if we whisper the word-call him the "President". Boulton was keen because he had the most to gain, as Keir remarked:

"Mr. B. is a proof how much sound knowledge may be acquirod without much regular study, by means of a quick and just apprehension, much practical application, and nice mechanical feelings. . . . It cannot be doubted that he was indebted for much of his knowledge to the best preceptor, the conversation of cminent men."

Dr. Erasmus Darwin ${ }^{5}$ (1731-1802) (Fig. 2) was the son of a country lawyer from Elston, noar Nottingham. After 3 years studying medicine at Cambridge and 2 more at Edinburgh, he began his medical practice in 1756. Impatient at the lack of patients in Nottingham, he moved to Lichfield (see Fig. 3), where he was offered a "hopeless" case, abandoned by other doctors. Darwin 
restored the patient to health, and from then on never looked back. He became recognized as the finest physician of his day, with a legendary reputation for curing "hopeless cases" and also for providing poor patients with food and blankets instead of charging fees. Darwin was immensely knowledgeable in all branches of science, and full of new ideas. He largely anticipated the theory of evolution developed by his grandson ${ }^{6}$; he explained the formation of clouds by the adiabatic expansion of moist rising air; he described photosynthesis in almost every detail; and he was a pioneer in the humane treatment of mental illness. Darwin was also an obsessive inventor, creator of a speaking machine, numerous improved carriages, and a horizontal windmill used for many years in Wedgwood's factory at Etruria, not to mention dozens of paper designs, including a canal lift, a drill plough, a steam carriage and even a flying machine. It is little wonder that Coleridge, although he disliked Darwin's atheism, his evolutionary ideas and his verse, wrote: "Dr. Darwin possesses, perhaps, a greater range of knowledge than any other man in Europe, and is the most inventive of philosophical men"7. Darwin was also a witty and forceful talker, who could be relied on to make the sparks fly at Lunar meetings.

\section{Sorry, for copyright reasons some images on this page may not be available online} Fig. 2. Dr. Erasmus Darwin. (By courtesy of the National Portrait

Darwin met Boulton in about 1758. Their interest in science was stimulated by Benjamin Franklin's visit to Birmingham in that year, and subsequently they often wrote to ask his advice about typically "Lunar" topics. Franklin, more than twenty years their senior, already had a world-wide reputation as a scientist, and can be regarded as the "favourite uncle" of the infant Lunar Society.

Darwin's idea for a four-wheeled twin-cylinder stcamcarriage with rear-wheel drive was proposed to Boulton in, probably, 1763 or 1764 . Darwin made drawings of the ingenious mechanism for this "fiery chariot", but his tremendous enthusiasm-" "I am quite mad of this Scheme", he said-was not enough to stampede Boulton into making what would have been the first steam carriage (if it had worked). Darwin's enthusiasm for steam engines remained, however, and played its part in inducing Boulton to join forces with Watt some years later.

In 1765 Dr. William Small ${ }^{8}(1734-1775)$ arrived in Birmingham with a letter of introduction from Franklin.
For the previous seven years, Small had been professor of natural philosophy at the College of William and Mary in Virginia, and one of his pupils, Thomas Jefferson, declared that Small's teaching "probably fixed the destinies of my life". In the next ten years Small earned the highest praise from all the Lunar circle for his profound learning and personal charm. He suffered continual ill health and died in 1775 at the age of 41 ; but in his ten years at Birmingham he did more than anyone else to weld together the members of the Lunar Society, espocially by his assiduous letter-writing.

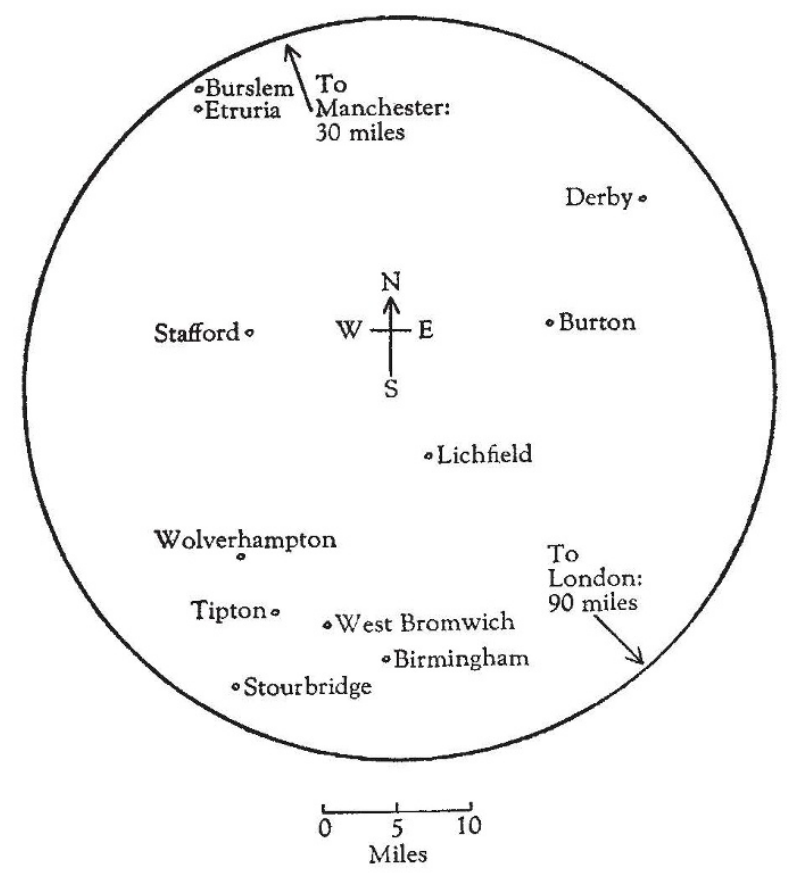

Fig. 3. Birmingham and the Lunar region.

If we formalize the informal by calling Boulton the President and Darwin the Vice-President of the Society, Small was the Secretary; and, as Oldenburg's contribution to the early Royal Society of London shows, the secretary could be all-important.

Of course the Lunar Society never had any such formal organization, but in 1765 Darwin did refer to the "Birmingham philosophers", a title which continued to be used for some years as the group grew in size. Because he met so many people in the course of his professional duties, Darwin also served as the "recruiting sergeant" for the Society and he introduced most of the new members. Josiah Wedgwood ${ }^{2}(1730-1795)$ is famous today for uniting and advancing science, art and industry in a manner never since equalled. With his new scientific processes in making pottery he was able to secure novel artistic effects, and his factory organization for an export drive offers an example which British manufacturers are often urged to follow today. Wedgwood began work in the family pottery at the age of nine, and by hard work acquired a business of his own in Burslem by 1759 . Wedgwood was often ill, and had a leg amputated in 1768. But he was immensely active, and in 1765 was engaged in the herculean task of promoting a new transport system, the Trent and Mersey canal, so that he could move his wares more cheaply and safely to the ports for shipping overseas. Darwin also suffered daily damage from the vile and bumpy roads of the time: he vigorously supported Wedgwood's campaign for the canal, for which a Parliamentary Bill was secured in 1766, and he introduced Wedgwood to Small and Boulton. Wedgwood did 
not attend Lunar Society meetings very often because he lived more than thirty miles from Birmingham, but he played his full part in the group and gained much from the chemical knowledge of some members and the industrial experience of others. Darwin remained his particular friend, however, and their families were linked when Darwin's son Robert married Wedgwood's daughter Susannah in 1796, and again when Robert's son Charles married Emma Wedgwood in 1839.

Richard Lovell Edgeworth ${ }^{10}(1744-1817)$ was heading for the way of life appropriate to a young Anglo-Irish landed gentleman when, in 1765 , he heard about a carriage peculiarly resistant to overturning, invented by Darwin. Edgeworth immediately decided to devote himself to invention, and from his retreat at Hare Hatch Common, near Reading, came a succession of ingenious devices, including a robot wooden horse, a carriage with sails, a telegraph, a turnip cutter, an umbrella for covering haystacks, and many more, some hare-brained and some eminently practical. Edgeworth's inventions won him gold and silver medals from the Society for the Encouragement of Arts, and kept the blacksmiths of Reading well employed.

In 1766 Edgeworth visited Lichfield. His inventiveness at once impressed Darwin and his charm impressed the ladies of Lichfield, two of whom he later carried off as his second and third wives. Darwin called in Boulton and Small to meet him, and from then onwards Edgeworth was firmly gripped in the Lunar circle. Whenever Edgeworth was in the neighbourhood he would attend Lunar meetings, and during his absences on his Irish estate at Edgeworthstown he kept up a lively correspondence on such subjects as education, railways and bog drainage.

The next recruit to the Lunar Society was James Keir ${ }^{11}$ (1735-1820). He was born in Edinburgh and was brought up with the Lind family. He went to the Edinburgh medical school with his cousin James Lind, afterwards physician to the Royal Household at Windsor. Keir became a friend of Darwin in 1755 when he was a medical student at Edinburgh. After some years in the Army, Keir decided that he had seen enough of foreign parts, and, in 1768, after a few months with Edgeworth at Hare Hatch, came to live at West Bromwich, a few miles west of Birmingham. Keir was soon absorbed into the Lunar group, and became one of the most popular members, often acting as chairman because of his sturdy common sense. Keir specialized in chemistry-Watt called him "a mighty chemist. . . and a very agreeable man"12_-and in 1780 he founded the Tipton alkali works, which might be said to mark the birth of the modern chemical industry. At Tipton, Keir succeeded in making soda from salt on a commercial scale, many years before the Leblanc process was heard of. Keir used a most ingenious method, in dilute solution, which has now at last been elucidated by J. L. Moilliet ${ }^{13}$.

It is a short step from Keir to the next and most famous member of the Lunar Society, James Watt ${ }^{14}$ (1736-1819) (Fig. 4). Watt was born at Greenock, near Glasgow, and after being apprenticed as a mathematical instrument-maker in London, he set up as "instrumentmaker to the University of Glasgow" in 1757. He quite soon turned his attention to steam engines, but it was not until May 1765 that Watt hit on the idea of the separate condenser for improving the engine's efficiency, a week or two after telling his friend (and Keir's cousin) James Lind, "I can think of nothing else but this engine. I hope to have the decisive trial before I see you". But soon afterwards Watt was obliged to take work as a surveyor, with his invention still not engineered, and in 1767 canal survey work brought him to London. On the way back he called on Darwin and Small, and to the steam-enthusiast Darwin he confided the secret of his invention. From this time until he came to live in Birmingham, Watt was a corresponding member of the Lunar Society.
In the late 1760s Watt's engine was being developed without much success by Dr. John Roebuck at Kinneil. In 1773 Roebuck's finances collapsed, and Boulton, urged on by Small and Darwin, bought up Roebuck's interest in the engine: the illustrious partnership of Boulton and Watt began in 1774. From then onwards Watt was one of the keenest Lunaticks and never missed a meeting without good cause. He gained much from the Society, not only ideas and criticisms, but also confidence. For the other members were full-blooded optimists and they talked Watt out of his innate pessimism, so that he achieved much he might otherwise never have attempted.

\section{Sorry, for copyright reasons some images on this page may not be available online}

Fig. 4. James Watt. (By courtesy of the National Portrait Gallery.)

In 1780 , when the Lunar Society was at its strongest, Dr. Joseph Priestley ${ }^{15}$ (1733-1804) (Fig. 5) came to live in Birmingham. Priestley was already famous for his researches in electricity and chemistry, but he regarded his religious activities (some called them irreligious) as equally important. He came to Birmingham because he had been appointed minister at New Meeting House. Priestley already knew most of the Lunar circle, and they quickly organized a subscription to provide him with funds for scientific work. The eleven years Priestley spent in Birmingham were the happiest and most productive of his life; he left under duress, after the riots when his house and all his belongings were destroyed by a mob. The excuse for the riots was a dinner on July 14 , 1791 , to mark the second anniversary of the storming of the Bastille. Most of the Lunar Society members had welcomed the French Revolution-Keir, perhaps the least revolutionary, being chairman at the dinner-and they were dismayed at the shouts heard during the riots, "No Philosophers-Church and King for ever". Priestley departed to London. But he was a marked man, and life became so difficult for him that he decided to emigrate to America in 1794.

Before Priestley left England he dedicated his Experiments on the Generation of Air from Water (1793) to the Society :

"There are few things that I more regret in consequence of my removal from Birmingham, than the loss of your society. It both encouraged and en- 
lightened me; so that what I did there of a philosophical kind ought in justice to be attributed almost as much to you as to myself. From our cheerful meetings I never absented myself voluntarily, and from my pleasing recollection they will never be absent."

\section{Sorry, for copyright reasons some images on this page may not be available online} Fig. 5. Dr. Joseph Priestley. (By courtesy of the National Fortrait

The Society Priestley knew in the 1780s had some new faces. Small died in 1775, and Darwin invited Dr. William Withering16 (1741-1799) to take over Small's medical practice in Birmingham and, as it turned out, also his place in the Lunar Society. Withering is now best known for his treatise on the medical uses of Digitalis (in $A n$ Account of the Foxglove, 1785), but the Lunar Society valued him most for his wide knowledge of chemistry, mineralogy and botany.

In 1781 Darwin himself moved from Lichfield after his second marriage, and his new home at Derby was more than 30 miles from Birmingham. So the meetings were enlivened by his wit and speculation far less often. But his letters of apology were almost as lively:

"Dear Boulton, I am sorry the infernal divinities who visit mankind with diseases . . . should have prevented my seeing all your great men at Soho today. Lord! what inventions, what wit, what rhetoric, metaphysical, mechanical and pyrotechnical, will be on the wing, bandied like a shuttlecock from one to another of your troup of philosophers! while poor I, I by myself I, imprison'd in a post-chaise, am joggl'd, and jostl'd and bump'd, and bruised along the King's highroad to make war upon a pox or a fever. . . ."17.

In 1782 Edgeworth departed to Ireland, to spend eight years on his estate at Edgeworthstown. No one could now reproach him for being an absentee landlord; instead he became an absentee Lunatick.

Just before Darwin's move to Derby, Samuel Galton ${ }^{18}$ (1753-1832) attended a Lunar meeting. It was the first of many, for Galton was a wealthy Quaker manufacturer who often entertained the Society at his house in Birmingham. Galton's scientific achievements were meagre, but Schofield has conclusively shown ${ }^{19}$ that he invented the colour top usually ascribed to Young, Helmholtz or Maxwell. Galton also contributed to the interlinking of
Lunar families, for his eldest son married Darwin's daughter Violetta: one of their sons was Sir Francis Galton, and one of their daughters married Keir's grandson James Moilliet.

The roll-call of Lunar Society members is now almost complete. Of the fourteen candidates accepted as authentic by Schofield, only four remain to be mentioned. The first of these is the most senior of all, John Whitehurst ${ }^{20}$ (1713-1788), an instrument-maker of Derby, celebrated for his fino clocks, and later equally famous as a geologist. He was a valued friend and adviser of Boulton and Darwin for more than twenty years, but he did not come to the meetings very often because he lived far away, at Derby, and even farther away after 1775 , when he moved to London.

The second of the final quartet is by far the most eccentric and least scientific of the Lunaticks, Thomas Day $^{21}$ (1748-1789). He was completely unconventional and yet he wrote that most proper of books, Sandford and Merton. He was the kindest of men and died on being thrown by an unruly horse which did not understand his theory of taming by kindness. Like several of the Lunaticks, he was keenly interested in Rousseau's educational ideas, and he put the matter to the test by adopting two girls from an orphanage and training them, in the hope that one might make a good wife for him. The experiment failed, and in the end it was the ever-helpful Dr. Small who found a wife for him. Day's contribution to the scientific side of Lunar meetings was probably negligible, but he was held in high regard by Edgeworth and Darwin.

The last two members ${ }^{22}$, Dr. Jonathan Stokes (17551831) and Rev. Robert Augustus Johnson (1745-1799), came to the Society late, in the 1780 s. Johnson was rather undistinguished, but Stokes was a genuine "Lunar type", a doctor in practice at Stourbridge, who was also an expert botanist and an experimenter in pneumatic chemistry. He might have carried the Society on into the nineteenth century, but unfortunately he quarrelled with Withering and rarely came to the meetings. On one wintry day in the 1790 s when he did come, ho brought in his pocl $t$ a frozen snake which, revived by the warmth, began slithering around the room.

For the Galton children who eaught it, the snake was merely amusing: yet it was also symbolic of the Lunar Society itself in the $1790 \mathrm{~s}$, largely frozen and only just thawed by the warmth of a meeting. And if anyone imagined that the hissing of the snake was symbolic of the steam going out of the Society, that steam had at least been put to good use: the Boulton and Watt engines, prime movers of the industrial revolution, would almost certainly never have come about without the web of Lunar friendship.

The Lunar Society, while it thrived, was by far the most. effective scientific association in Britain. The Royal Society of London had declined between 1700 and 1750 , with the successive deaths of the great seventeenthcontury figures such as Hooke, Newton and Halley, and the election of too many non-scientists. 'The renewal of vigour in the Royal Society came during the 1780 s soon after Sir Joseph Banks began his forty-two years as president. Members of the Lunar Society played a leading part in this revival, for all but three of them (Day, Small and Stokes) had become Fellows of the Royal Society by 1790 . Pricstley was the most prolific, with his mary papers on "airs" in the Philosophical Transactions. Darwin was the sonior (he was elected a Follow of the Royal Society in 1761), and in the 1780 s contributed his important papers on artesian wolls and the formation of clouds. Boulton wrote nothing for the Philosophical Transactions; Withering wrote mainly on mineralogy; and Wedgwood described his experiments with pyrometers, which no one else could reproduce for many years. Watt contributed his theory of the composition of water, and started the famous "Water Controversy". Keir 
wrote about the theory of chemical solutions, a difficult subject which he did little to elucidate, despite the cunning use of solutions in his soda process. Edgeworth's experiments on carriage springs were (wrongly) not thought worthy of publication, but his classic paper on the air resistance of projectiles appeared in the Philo. sophical Transactions. The Lunar members formed a strong technological contingent in the Royal Society and kept it in touch with practical industry.

"Practical" is an adjective that sums up the Lunar Society rather well (except for their failure to take notes of their proceedings). The very dates of their meetings were chosen with the aim of having some moonlight to guide them on their way home afterwards, clouds permitting. They were also "practical" in the sense that they were mostly self-made men, who started from little and achieved much. (The exceptions were Edgeworth and Day, who came from moneyed families.) They represent the thrusting, up-and-coming provincial men who held the key to the future, and they stood opposed to the assured and often effete aristocracy who held governmental power in London. Few of the members supported the Church of England, though their form of heresy varied from rank atheism to high-minded Unitarianism.

The Lunaticks were also fairly radical in their political views, welcoming the French Revolution and supporting the campaign for the abolition of slavery. Darwin, who won a brilliant reputation for a few years in the early 1790s with his seientific poem The Botanic Garden, tells us how the "Giant-form" of Liberty had in France long slept, "unconscious of his chains":

"Round his large limbs were wound a thousand strings By the weak hands of Confessors and Kings...

Touch'd by the patriot-flame, he rent amazed

The flimsy bonds ...." ${ }_{23}$.

In the repressive atmosphere of the 1790 s such references to churchmen and kings were resented, and Darwin eame under political attack which clouded his reputation. The campaign against slavery was helped most by Wedgwood, who distributed hundreds of cameos of a slave in chains, with the telling inscription "Am I not a man and a brother?"

Every article about the Lunar Society is unsatisfactory, because the Society dissolves like a mirage as you approach and leaves you with little but the individual acts of these fourteen apostles of progress. Still, it is possible to piece together a rather fuzzy picture of a typical meeting.

The philosophers, perhaps six or eight of them, would meet at one or other of their houses, but most often Boulton's, from about 2 in the afternoon until about 8 in the evening, though the times may have varied with the season. 'The first item on the agenda, and the only regular one, was a good meal. The intellectual menu began simultaneously as one member or another raised the scientific topic dearest to his heart, and let the other members "bandy it about like a shuttlecock". Experiments to test the idea would be suggested and one or more members would agree to do the experiments and report the results. The meetings were usually held on the Sunday before full Moon; but when Priestley joined, the day was changed to Monday, because his priestly duties prevented his attending on a Sunday. The meetings did not occur every month: entertaining a troop of hungry philosophers was not a task to be lightly undertaken, and several months often passed between gatherings, especially when Boulton was away. Even the habit of meeting at the time of the full Moon did not become established until the Society was more than ten years old. These untidy aspects of the Society merely illustrate the profound half-truths that creative minds do not need organizing and that any activity in the grip of formal organization is already decaying.

For one meeting, in 1781, we do know something of the agenda, from the invitation Watt sent to Darwin:
"I beg that you would impress on your memory" the idea, that you promised to dine with sundry men of learning at my house on Monday next, and that you will realize that idea. For your encouragement, there is a new book to eut up; and it is to be determined whether or not heat is a compound of phlogiston and empyreal air, and whether a mirror can reflect the heat of a fire. I give you a friendly warning that you may be found wanting, whichever opinion you adopt in the latter question; therefore be cautious. If you are meek and humble, perhaps you may be told what light is made of, and also how to make it, and the theory proved both by synthesis and analysis." 24 .

The bantering tone shows how the Lunaticks, even after fifteen years of meetings, avoided taking themselves too seriously. They knew that solemnity all too soon engenders rigidity, and is no friend to science.

The only account of Lunar meetings by an outsider comes from Galton's daughter Mary Anne (who caught the snake). Unfortunately she was very young (between eight and twelve years old) when she observed the meetings. And, even more unfortunately, she was unreliable and a mischief-maker: according to a marginal note by her nephew Sir Francis Galton, her malicious gossip "broke off eleven marriages" ${ }^{25}$. Although the story of the snake is too good to suppress, little credence can be placed in the rest of her report.

Perhaps the best tribute to the Lunar Society and the sharpest riposte to those who question its existence come from Joseph Priestley's Memoirs.

"I consider my settlement at Birmingham as the happiest event in my life, being highly favourable to every object I had in view, philosophical or theological.... I I had... the society of persons eminent for their knowledge of chemistry, particularly Mr. Watt, Mr. Keir, and Dr. Withering. These with Mr. Boulton and Dr. Darwin ... Mr. Galton, and afterwards Mr. Johnson of Kenilworth and myself, dined together every month, calling ourselves the lunar society, because the time of our meeting was near the full moon."26.

If anyone requires a date and a place for the beginning of the modern world, it would be difficult to find better ones than 1766 and Birmingham, coupled with the name of the Lunar Society, the greatest of scientific nonorganizations.

${ }^{1}$ Edgeworth, R. L., and Maria, Memoirs of Richard Lovell Edgeworth, third ed, 116 (London, 1844).

2 Dickinson, H. W., Matthew Boulton (Cambridge Univ. Press, 1937).

${ }^{3}$ Schofield, R. E., The Lunar Society of Birmingham (Oxford Univ. Press, 1964).

4 Schofield, R, E, ref, 3 , p. 18 .

${ }^{3}$ King-Hele, D. G., Erasmus Darwin (Macmillan, 1963).

' King-Hele, D. G., Nature, 200, 304 (1963).

7 Coleridge, S. T., Collected Letters, 1, 177 (Oxford Univ. Press, 1956).

${ }^{8}$ See Schofield, R. E., ref. 3. pp. 35-39 and 68-72.

- Meteyard, E., The Life of Josiah Wedgwood (Hurst and Blackett, 1865-6).

${ }^{10}$ Clarke, D., The Ingenious Mr. Edgeworth (Oldbourne, 1965).

${ }_{11}$ Moilliet, J. K., Life and Correspondence of James Keir (privately printed. 1868).

${ }^{12}$ Muirhead, J. P., The Origins and Progress of the Mechanical Inventions of James Watt, 1, 32 (Murray, 1854).

${ }^{13}$ Moilliet, J. L., Chem. and Indust., No. 10, 405 (1966).

${ }^{14}$ Rolt, L. T. C., James Watt (Batsford, 1962). Crowther, J. G., Scientists of the Industrial Revolution, 93-172 (Cresset Press, 1962).

Is Gibbs, F. W., Joseph Priestley (Nelson, 1965). Crowther, J. G., Scientists

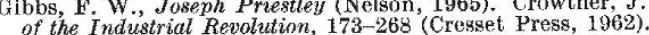

${ }_{16}$ Peck, T. W., and Wilkinson, K. D., William Withering of Birmingham (Wright, Bristol, 1950).

17 Robinson, E., Ann. Sci., 9, 359 (1953).

${ }_{18}$ Pearson, K., The Life, Letters and Labours of Francis (ralton, 1 (Cambridge Univ. Press, 1914).

${ }^{19}$ Schofield, R. E., ref. 3, pp. 270-2.

20 Schofield, R. E., ref. 3, pp, 21-3 and 127-8.

${ }^{21}$ Scott, S. H., The Exemplary Mr. Day (Faber, 1935).

${ }^{22}$ Schofield, R. E., ref. 3 , pp. 223-30.

${ }^{23}$ Darwin, E., The Botanic Garden, Part I, Canto II, lines 379-80 and $385-6$ (Johnson, 1791).

${ }^{24}$ Muirhead, J. P., ref. 12, 2, 123.

2s Pearson, H, Doctor Darwin, 88 (Penguin, 1943 ).

${ }^{26}$ Priestley, J., Memoirs, 1, 97 (Johnson, 1806) (quoted from ref. 3, p. 366). 